\title{
Tonicity induced changes in volume and refractive index of suspended cells quantified with digital holographic microscopy
}

\author{
B. Kemper, ${ }^{* 1}$ J. Klokkers, ${ }^{2}$ S. Przibilla, ${ }^{1}$ A. Vollmer, ${ }^{1}$ S. Ketelhut, ${ }^{1}$ G. von Bally, ${ }^{1}$ E. Schlatter, ${ }^{2}$ \\ H. Pavenstädt, ${ }^{2}$ and B. Edemir ${ }^{2}$ \\ ${ }^{I}$ Center for Biomedical Optics and Photonics, University of Muenster, Robert-Koch-Str. 45, \\ D-48149 Muenster,Germany \\ ${ }^{2}$ Department of Internal Medicine D, University of Muenster, Albert-Schweitzer-Campus 1, A 14, \\ D-48149 Muenster, Germany
}

Received May 25, 2012; accepted June 23, 2012; published June 30, 2012

\begin{abstract}
The analysis of changes in the volume and intracellular solute concentrations of biological cells represents an important topic in cytometry. We present results from a comparative study in which the cell volume and the refractive index of living rat inner medullary collecting duct cells and human pancreatic tumor cells was determined in media with different tonicity by using quantitative digital holographic phase microscopy. The results show that the inverse cell volume correlates linearly with the integral cellular refractive index which is directly related to the concentration of intracellular solutes.
\end{abstract}

The volume of biological cells depends mainly on the intracellular concentration of osmotic active compounds because the outer plasma membrane is highly permeable to water compared to solutes like $\mathrm{Na}^{+}, \mathrm{K}^{+}$, or $\mathrm{Cl}^{-}$. A decrease of the extracellular tonicity leads to an increase of the cellular volume. An increase of the extracellular tonicity is followed by a decrease of the cell volume. Factors and underlying mechanisms for the regulation of the cell volume maintenance are summarized e.g. by Hoffmann et al. [1]. Beside other factors the activation of several transport proteins is involved in the cell volume regulation. These include $\mathrm{Cl}^{-}$channels, $\mathrm{K}^{+}$channels or proteins participating in the osmolyte release pathway. Prominent transporters belong to the family of $\mathrm{Na}^{+} / \mathrm{H}^{+}$ exchangers (SLC9), $\mathrm{Na}^{+}-\mathrm{K}^{+}-2 \mathrm{Cl}^{-}$co-transporters (SLC12) or to transporters involved in the uptake of organic osmolytes [1]. To reveal the function of such transporters in cell volume regulation the cellular volume and the density of intracellular solutes has to be quantified. However, simultaneous measurement of these parameters is a challenging and a variety of experimental approaches have been proposed. For example, cell volume changes were detected utilizing fluorescent probes [2], laser scanning microscopy [3] and electronic sizing with a flow cytometer [4]. In contrast to [2-4], digital holographic microscopy (DHM) [5-8] enables minimally invasive live cell analysis by quantitative multi-focus phase contrast imaging without the need of labeling or complex sample

*E-mail: bkemper@uni-muenster.de preparation. Furthermore, DHM provides not only access to the cell volume but also information about the refractive index of adherent [8-10] and suspended single cells [11-13], which is directly related to the intracellular solute concentration [14], as well as capabilities for refractive index tomography [15-18]. Thus, in this study we used DHM to analyze the absolute cell volume and the mean refractive index of primary cultured inner medullary collecting duct (IMCD) cells [19], which are capable to tolerate large changes in extracellular osmolalities. We also compared the obtained data to the results obtained from pancreatic tumor cells (PaTu $8988 \mathrm{~T}$ ) [8]. IMCD cells were initially cultivated at $600 \mathrm{mOsmol} / \mathrm{kg}$ as described in [19]. The PaTu 8988 T cells were cultivated under typical cell culture conditions at $320 \mathrm{mOsmol} / \mathrm{kg}$ (for details see the description in [8]). For measurements both cell types were trypsinized and suspended to Petri dishes with a HEPES buffered medium. IMCD cells were investigated in MEM (Modified Eagle Medium) while PaTu 8988 T cells were observed in DMEM (Dulbecco's Modified Eagle Medium). In order to stimulate the IMCD cells, starting from the initial medium of $600 \mathrm{mOsmol} / \mathrm{kg}$ equimolar amounts of $\mathrm{NaCl}$ and urea were added or the medium was diluted with deionized water in order to increase or decrease the osmolality. For hypotonic stimulation of PaTu $8988 \mathrm{~T}$ cells the initial medium of $320 \mathrm{mOsmol} / \mathrm{kg}$ was diluted by deionized water while investigations with hypertonic medium were performed with a solution generated by diluting a concentrated version of DMEM (10x). For quantitative DHM phase contrast imaging of the IMCD cells an inverted microscope (iMIC, Till Photonics, Gräfelfing, Germany) was used with an attached digital holographic add-on module as described in [120]. The PaTu $8988 \mathrm{~T}$ cells were analyzed with a self-interference DHM setup based on a Zeiss Axio Observer A1 microscope (Carl Zeiss MicroImaging GmbH, Germany) [21]. In both experimental setups the coherent light source for the recording of digital holograms was a frequency doubled 
Nd:YAG laser (Compass 315M-100, Coherent, Lübeck, Germany, $\lambda=532 \mathrm{~nm}$ ). Prior to each measurement with digital holographic microscopy cells were equilibrated for $5 \mathrm{~min}$ in the respective medium. Then digital off-axis holograms of cells with mainly spherical appearance were recorded. For each osmolality $N=86-164$ cells were recorded at room temperature $\left(T=22^{\circ} \mathrm{C}\right)$ during the following $20 \mathrm{~min}$. A numerical reconstruction of digitally captured holograms was performed by spatial phase shifting reconstruction as described in $[5,8]$ combined with digital holographic autofocusing [22]. From the resulting quantitative phase images an average cell radius $R$ and an average integral cellular refractive index $n_{\text {cell }}$ were obtained for each cell by two dimensional fitting of the sphere model as described in detail in [13]. Assuming a mainly spherical shape of the suspended cells an average cell volume was calculated from obtained cell radii $R$ while a simultaneously obtained parameter $n_{\text {cell }}$ was used to characterize intracellular solute concentration.
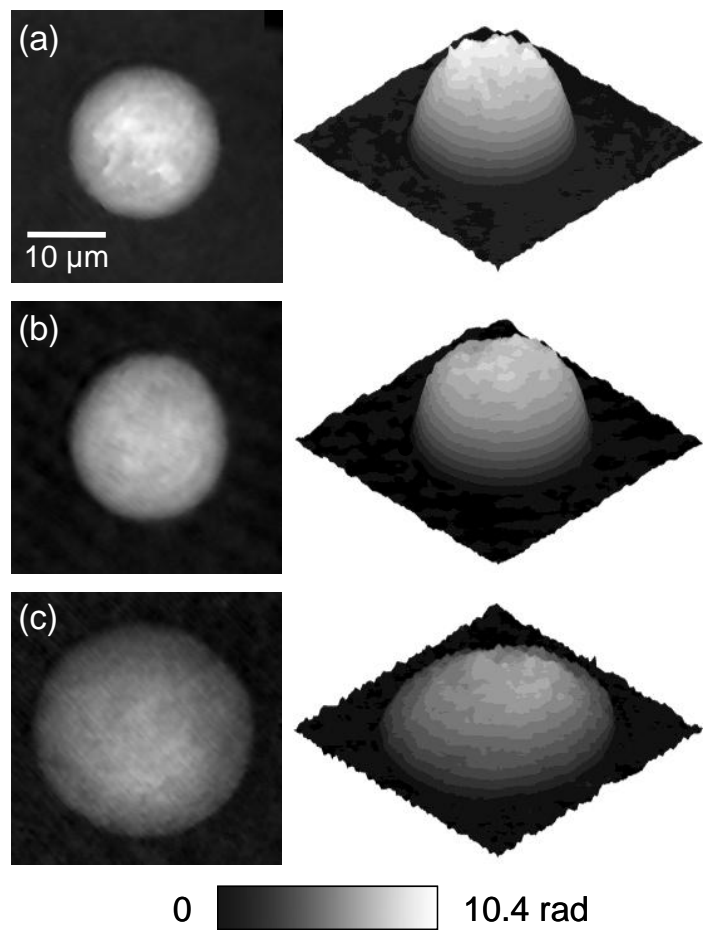

Fig. 1. Representative DHM phase contrast images of trypsinized IMCD cells coded to 256 gray level (left column) and corresponding pseudo 3D plots (right column). (a): $1200 \mathrm{mOsmol} / \mathrm{kg}$, (b): 600 $\mathrm{mOsmol} / \mathrm{kg}$, (c): $200 \mathrm{mOsmol} / \mathrm{kg}$.

Figure 1 (left column) illustrates representative quantitative DHM phase images of trypsinized IMCD cells (coded to 256 gray levels) for $1200 \mathrm{mOsmol} / \mathrm{kg}$ (Fig. 1a), $600 \mathrm{mOsmol} / \mathrm{kg}$ (Fig. 1b) and $200 \mathrm{mOsmol} / \mathrm{kg}$ (Fig. 1c). The gray levels of all images are normalized to the maximum phase contrast that was detected for the phase distribution in Fig. 1a. The corresponding gray level coded pseudo 3D plots of phase images are depicted on the right column of Fig. 1. The cell volume increases with decreasing osmolality. Simultaneously, the phase contrast decreases as the integral cellular refractive index decreases due to water influx. Fig. 2 shows the dependency of the cell volume from the osmolality for IMCD and PaTu 8988 T cells. For both cell types the cell volume decreases non-linear (Figs. 2a and 2c). For example, at $150 \mathrm{mOsmol} / \mathrm{kg}$ the IMCD cells double their average volume compared to the $600 \mathrm{mOsmol} / \mathrm{kg}$. The application of $1200 \mathrm{mOsmol} / \mathrm{kg}$ results in a volume decrease to about $50 \%$ of the initial values. For the data from the PaTu $8988 \mathrm{~T}$ cells a similar course is observed while the absolute volume values are lower than for the IMCD cells. The corresponding refractive index values in Figs. 2c and $2 \mathrm{~d}$ increase in the range from $150 \mathrm{mOsmol} / \mathrm{kg}$ to $600 \mathrm{mOsmol} / \mathrm{kg}$ almost linear while for higher osmolality the saturation behavior is observed.
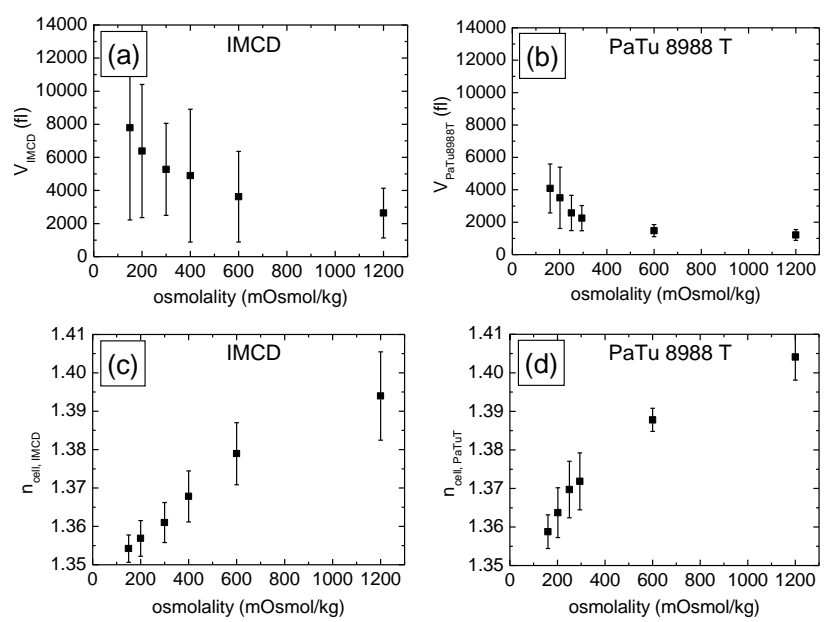

Fig. 2. Osmolality induced changes in cell volume $V$ and refractive index $n_{\text {cell }}$. (a), (c): volume and refractive index of IMCD cells, (b), (d): volume and refractive index of PaTu8988 T cells $(N=86-164$ cells were analyzed for each osmolality and cell type, error bars represent the standard deviation of the mean value).

In Fig. 3, for both cell types the mean cellular refractive index - in dependence of the inverse cell volume - is plotted. The comparison to a linear fit (see solid lines in Figs. 3a-b) illustrates that for both, IMCD cells and PaTu $8988 \mathrm{~T}$ cells, $n_{\text {cell }}$ is proportional to $1 / \mathrm{V}$ while different slopes quantify individual responses of the cells to osmotic stimulation. The cellular refractive index reflects the concentration of cellular components like proteins, solutes, and organelles [14]. A refractive index decrease indicates the dilution of these factors. Thus, from the linear relation between $n_{\text {cell }}$ and $1 / \mathrm{V}$ it can be concluded that refractive index changes are mainly caused by the water uptake of the cells while the amount of 
intracellular substances stays constant. This indicates that the observed changes in cellular volume are due to increased or decreased water content of the cells and not exchanges of intracellular solutes.
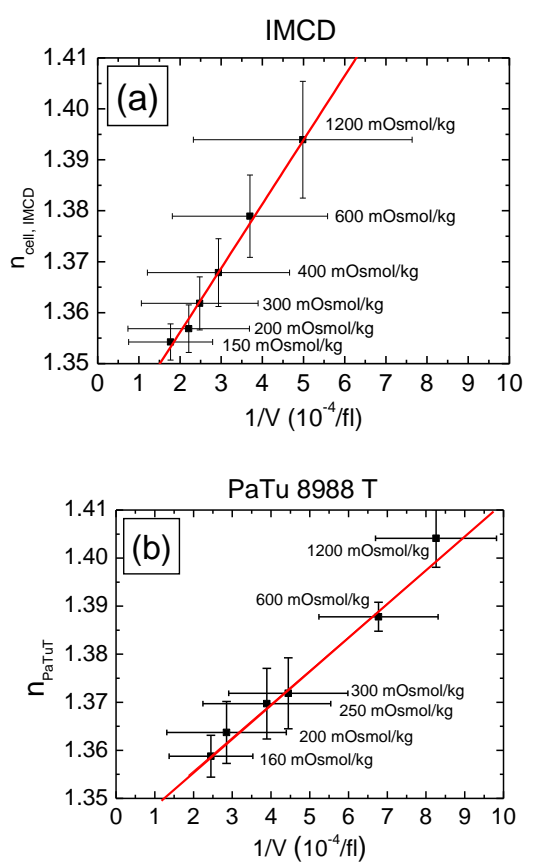

Fig. 3. Mean integral cellular refractive indices $n_{\text {cell, IMCD }}, n_{\text {cell, PaTuT }}$ versus the reciprocal cell volume $V$. The solid lines represent linear fits to the experimental data. The values near the data points indicate the osmolality of the media. (a): IMCD cells; (b): PaTu 8988 T cells $(N=86-164$ cells were analyzed for each osmolality and cell type, error bars represent the standard deviation of the mean value).

In conclusion, we show that in primary cultured IMCD and pancreatic tumor cells changes in the cell volume and integral cellular refractive index induced by differences in extracellular osmolality can be reliably quantified by DHM. To the best of our knowledge we demonstrate for the first time that the mean refractive index of living suspended single cells is linearly related to the inverse cell volume within a wide range of osmolalities. As the cellular refractive index is directly related to the dry mass [14, 23-24], it can be concluded that the absolute cell content stays constant within the measurement accuracy. The obtained results open up future prospects for the application of DHM quantitative phase imaging in phenotyping cytometry, and for further studies on mechanisms involved in cell volume regulation.

\section{Acknowledgements}

Financial support is gratefully acknowledged, provided by the German Federal Ministry for Education and Research (BMBF) as part of the "Biophotonics" research program (FKZ13N10937) and the IMF SC520801. Furthermore, the authors thank Christina Rommel and Jürgen
Schnekenburger from the Biomedical Technology Center of the Medical Faculty of the University of Muenster for their support with the pancreatic tumor cells.

\section{References}

[1] E.K. Hoffmann, O.H. Lambert, S.F. Pedersen, Physiol. Rev. 89, 193 (2009).

[2] W.E. Crowe, J. Altamirano, L. Huerto, F.J. Alvarez-Leefmans, Neuroscience 69, 283 (1995).

[3] K. Maric, B. Wiesner, D. Lorenz, E. Klussmann, T. Betz, W. Rosenthal, Biophys. J. 80, 1783 (2001).

[4] K.A. Poulsen, E.C. Andersen, C.F. Hansen, T.K. Klausen, C. Hougaard, I.H. Lambert, E.K. Hoffmann, Am. J. Physiol. Cell Physiol. 298, C14 (2010).

[5] D. Carl, B. Kemper, G. Wernicke, G. von Bally, Appl. Opt. 43, 6536 (2004).

[6] P. Marquet, B. Rappaz, P.J. Magistretti, P.E. Cuche, Y. Emery, T. Colomb, C. Depeursinge, Opt. Lett. 30, 468 (2005).

[7] C.J. Mann, L.F. Yu, C.M. Lo, M.K. Kim, Opt. Expr. 13, 8693 (2005).

[8] B. Kemper, D. Carl, J. Schnekenburger, I. Bredebusch, M. Schäfer, W. Domschke, G. von Bally, J. Biomed. Opt. 11, 034005 (2006).

[9] B. Rappaz, P. Marquet, E. Cuche, Y. Emery, C. Depeursinge, P.J. Magistretti, Opt. Expr. 13, 9361 (2005).

[10] B. Rappaz, F. Charrière, C. Depeursinge, P.J. Magistretti, P. Marquet, Opt. Lett. 33, 744 (2007).

[11] B. Kemper, S. Kosmeier, P. Langehanenberg, G. von Bally, I. Bredebusch, W. Domschke, J. Schnekenburger, J. Biomed. Opt. 12, 054009 (2007).

[12] M. Kemmler, M. Fratz, D. Giel, N. Saum, A. Brandenburg, C. Hoffman, J. Biomed. Opt., 12, 064002 (2007).

[13] S. Kosmeier, B. Kemper, P. Langehanenberg, I. Bredebusch, J. Schnekenburger, A. Bauwens, G. von Bally, Proc SPIE 6991 699110 (2008).

[14] R. Barer, "Interference microscopy and mass determination," Nature (London) 169, 366 (1952).

[15] F. Charrière, N. Pavillon, T. Colomb, C. Depeursinge, T.J. Heger, E.A.D. Mitchell, P. Marquet, B. Rappaz, Opt. Expr. 14, 7005 (2006).

[16] W. Choi, C. Fang-Yen, K. Badizadegan, S. Oh, N. Lue, R.R. Dasari, M.S. Feld, Nat. Meth. 4, 717 (2007).

[17] M. Debailleul, V. Georges, B. Simon, R. Morin, O. Haeberlé, Opt. Lett. 34, 79 (2009).

[18] T. Kozacki, R. Krajewski, M. Kujawińska, Opt. Expr. 17, 13758 (2009).

[19] J. Klokkers, P. Langehanenberg, B. Kemper, S. Kosmeier, G. von Bally, C. Riethmuller, F. Wunder, A. Sindic, H. Pavenstädt, E. Schlatter, B. Edemir, Am. J. Physiol. Renal. Physiol. 297, F693 (2009).

[20] B. Kemper, D. Carl, A. Höink, G. von Bally, I. Bredebusch, J. Schnekenburger, Proc. SPIE 6191, 61910T (2006).

[21] B. Kemper, A. Vollmer, C. Rommel, J. Schnekenburger, G. von Bally, J. Biomed. Opt. 16, 026014 (2011).

[22] P. Langehanenberg, B. Kemper, D. Dirksen, G. von Bally, Appl. Opt. 47, D176 (2008).

[23] B. Rappaz, E. Canob, T. Colomb, J. Kühn, V. Simanis, C. Depeursinge, P.J. Magistretti, P. Marquet, J. Biomed. Opt. 14, 034049 (2009).

[24] G. Popescu, Y.K. Park, N. Lue, C.-A. Best-Popescu, L. Deflores, R.R. Dasari, M.S. Feld, K. Badizadegan, Am. J. Physiol. Cell Physiol. 295, C538 (2008) 